\title{
Digitising Context
}

\section{The Case Of The Radio Times}

\author{
Andy 0'Dwyer \\ BBC Research I Centre House, Wood Lane \\ W12 7SB London I United Kingdom | Andy.O'Dwyerabbc.co.uk
}

\begin{abstract}
The BBC is placing online their complete TV and radio schedule information going back to the formation of the BBC in 1922. For the very first time, the public, students and academics will be available to browse through detailed information on the BBC's broadcasting history. This has been made possible by a large scanning project of the BBC's programme guide magazine, the Radio Times. Over eighty years of programme information has been scanned, digitised and made ready for access via the Internet. It will be possible to search through years, months and days to see programme titles. There will also be descriptions about these programmes as reflected in the Radio Times and information on the contributors, performers, directors and producers.

Keywords: audiovisual archives, broadcasting history, Radio Times, programme guides, book scanning
\end{abstract}

\section{Background}

The Radio Times is the UK's most popular weekly schedules magazine for radio and television. The BBC first published it in 1923 when newspapers considered radio a rival service and were reluctant to carry scheduling information. There are various editions printed for the nations and regions that carry local programme information. The magazine is funded through a mixture of sales and advertising. In August 2011 BBC Worldwide (the commercial arm of the BBC) announced that it had sold 'BBC Magazines' which included the Radio Times to the company Exponet. ${ }^{1}$

Before 1991 (when deregulation was introduced) the BBC had exclusive rights to print its weekly radio and television schedules, with newspapers given permission to carry daily schedule information for their readers. Since then numerous magazines carry television and radio information across both analogue and digital services. In spite of these competing magazines, the Radio Times has continued to be the number one selling weekly radio and television schedule magazine. ${ }^{2}$ 


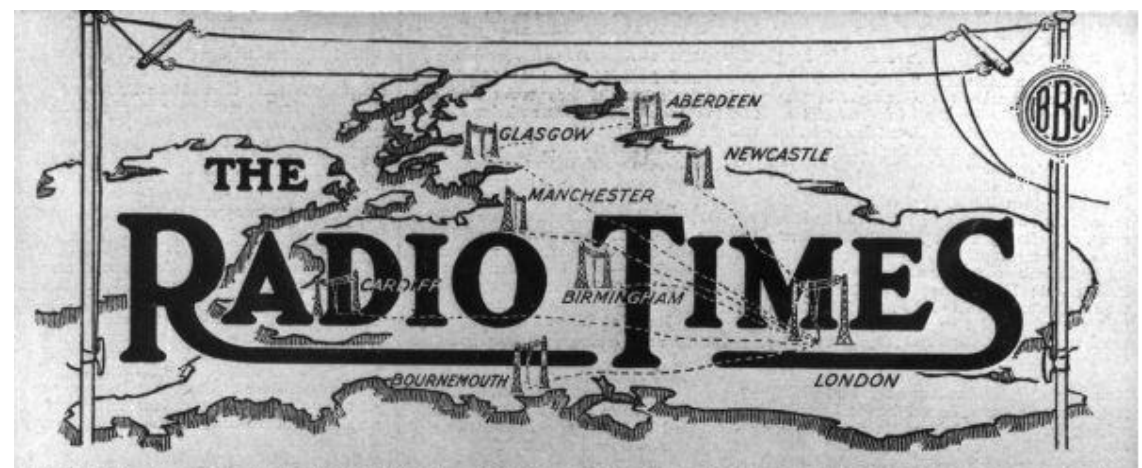

Masthead of the first edition 28th September 1923

\section{Cultural Significance}

Because the Radio Times magazine has been in near continuous production for over eighty years it has become a cultural institution. Most people in Britain have grown up with it in the home. As well as carrying the scheduled and frequency information for radio and later television, it includes editorial articles on new productions, interviews with playwrights and actors. Plus it carries letters from viewers and listeners commenting on the current output of the BBC.

It is this length of service and historical information that makes the Radio Times a significant resource for study. It is of interest to many disciplines from the social sciences and humanities through to media and technology. The magazine has literally charted and reported on decades of UK social, economic and political developments including national and international events; from state occasions and Royal weddings in the UK to international moments such as Football's World Cup and entertainment like the Eurovision Song Contest. Many of these moments were reported on radio and television and contextualized in the Radio Times with unique feature articles and photographs.

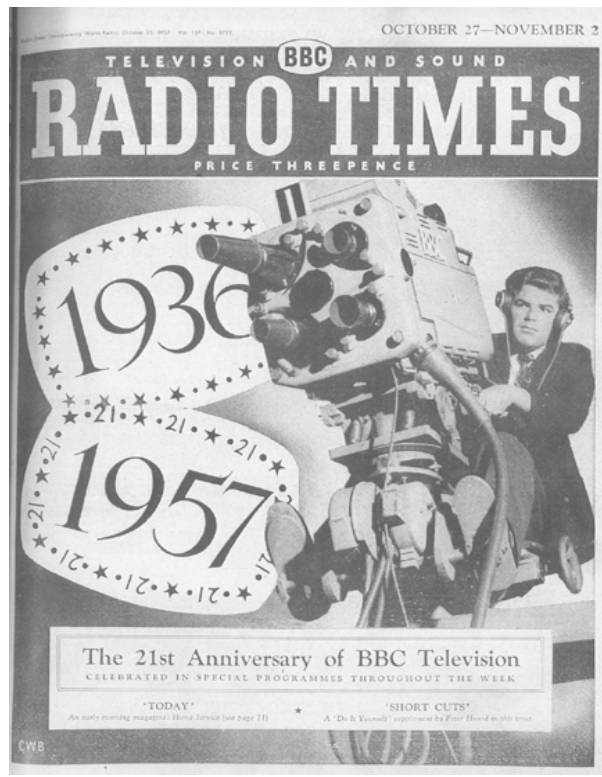

1957: TV's 21st Anniversary

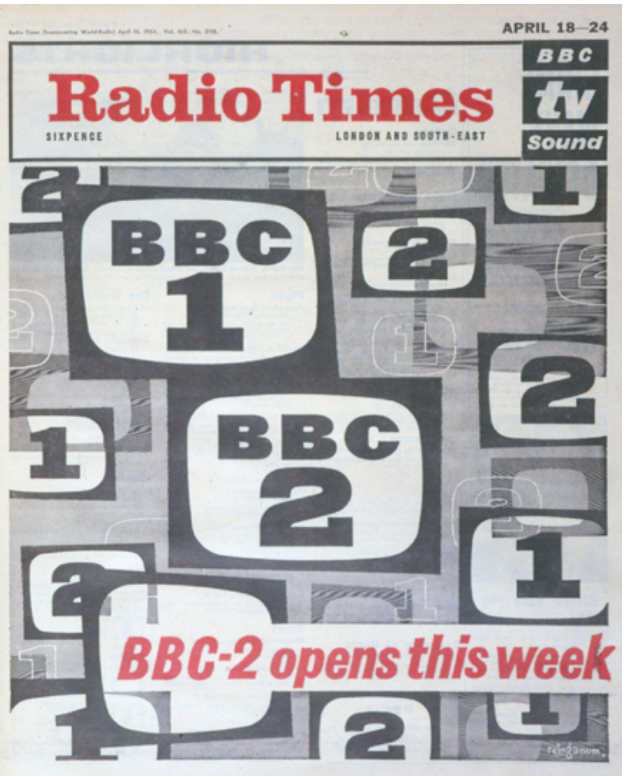

The start of BBC2 in 1967

For historians of media technology the magazine is of high value as the BBC were often the first with, or contributed to, many new technological developments promoted on television and radio. And the Radio Times would have written about it. This is particularly true in the area of international broadcasting standards and link ups. 
Through its membership of bodies such as the European Broadcasting Union (EBU) the BBC has participated in European and transatlantic programme exchange which the Radio Times has reported upon. Adding context and illustrations to maps and articles, the magazine often combined contributions from leading people of the time to help viewers understand these new developments.

\section{Digitisation Of The Radio Times: Online Public Access}

The BBC has announced that it is planning to provide the public with online access to the broadcast history of the $\mathrm{BBC}$ across radio and television. To do this the back catalogue of the Radio Times is being scanned and optical character recognition software (OCR) applied. Called the Genome project ${ }^{3}$ it is anticipated that over 360,000 pages will be digitised. For the first time ever it will be possible to search and discover the range of programmes put out by the BBC over the decades through year, month or day.

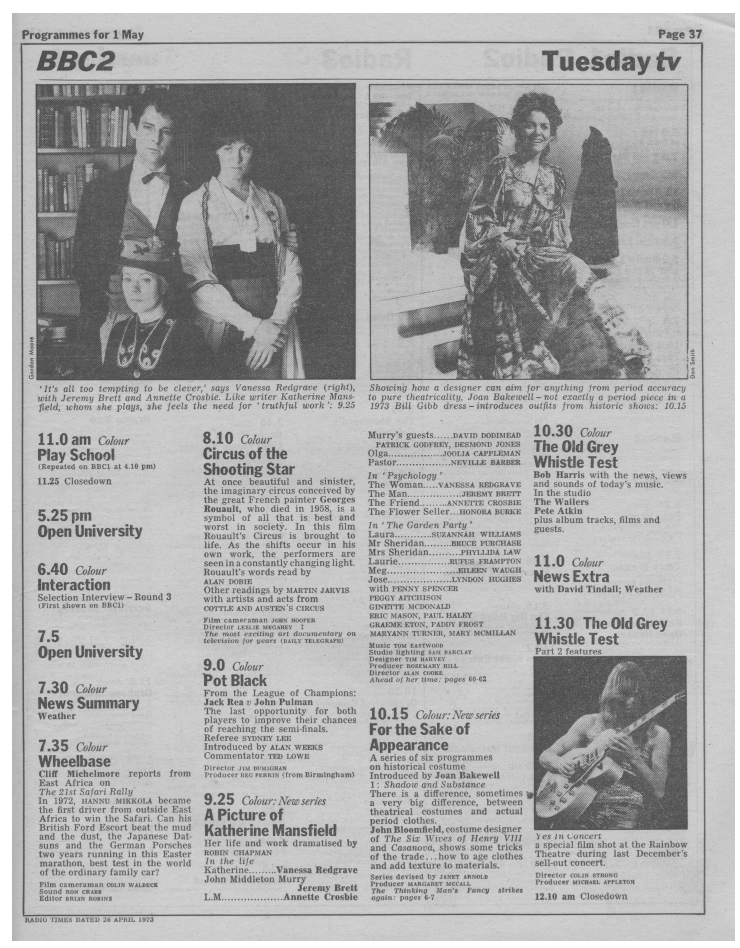

Example of a typical schedules page for TV

It will be possible to see the credits of programmes, which often include details of cast lists, directors and producers. It will be searchable, making it a valuable resource for study. If there was a summary about the programme describing what it was about in the Radio Times this will also be made available online.

The Radio Times digitisation project is just one of a set of initiatives the BBC has initiated on public access. In May 2009, the Director of Archive Content in the BBC, Roly Keating 4 gave a speech in London which focused on the aspirations of opening up the BBC's wealth of archive content. He spoke in particular about the BBC being 'a resource for the nation' 5 and defined four values:

- Educational value

- Cultural Value

- Entertainment \& nostalgia

- Personal interest

3 http://www.bbc.co.uk/blogs/aboutthebbc/2011/10/bbc-genome-update-search-disco.shtml

4 http://www.bbc.co.uk/pressoffice/biographies/biogs/controllers/rolykeating.shtml

5 FOCAL International:Jane Mercer Memorial Lecture 19th May 2009 


\section{The Radio Times As A Navigation Tool Into The BBC Collections?}

When the BBC places content online, how will the public search through it? There are thousands of radio and television programmes with little or no cataloguing and finding material in detail may be difficult. As the Radio Times is a familiar timeline of the BBC's output, it could act as a natural navigation path into the collections.

Programmes across radio and television have additional items that could be useful for the public and educational users. Scripts, photographs, and personal memories of presenters, actors and technicians can be linked to the programme and help to bring more knowledge and understanding of broadcasting.

\section{Conclusion}

Scanning the Radio Times and unlocking decades of schedule information will be useful for many types of users from media professionals, the education sector and public. They will all be able to learn about the output of broadcasting from September 1923 up to modern times.

This is only one of a number of initiatives by the BBC to make various forms of content available. And where there is a relationship between items such as scripts, photographs and documents to a particular programme or series, these will be linked making it easier for the user to search across different collections more efficiently.

It is very likely we are all going to be enriched with information and knowledge by browsing through the Radio Times schedules. As taking a journey through the BBC's broadcasting output reflects on so many other aspects of history.

\section{Biography}

Andy O'Dwyer is a Technologist/Project Manager at the BBC. He is currently working on initiatives to bring online audiovisual collections. He is active on a number of EU collaborative projects to support public and academic use of archival material, such as AXES and EUscreen. As a member of the Television Studies Commission of FIAT, he promotes new techniques in linking audiovisual material with the education sector. He is a member of the European Television History Network, and a contributing author of the book 'A European Television History'. 